\title{
Contemporary experience with high-dose interleukin-2 therapy and impact on survival in patients with metastatic melanoma and metastatic renal cell carcinoma
}

\author{
Ajjai Alva ${ }^{1}$ - Gregory A. Daniels ${ }^{2} \cdot$ Michael K. K. Wong ${ }^{3,4} \cdot$ Howard L. Kaufman $^{5} \cdot$ Michael A. Morse $^{6}$. \\ David F. McDermott ${ }^{7} \cdot$ Joseph I. Clark $^{8} \cdot$ Sanjiv S. Agarwala9 $^{9}$ Gerald Miletello $^{10} \cdot$ Theodore F. Logan $^{11}$. \\ Ralph J. Hauke ${ }^{12}$ Brendan Curti ${ }^{13} \cdot$ John M. Kirkwood ${ }^{14} \cdot$ Rene Gonzalez $^{15} \cdot$ Asim Amin $^{16}$ • Mayer Fishman ${ }^{17}$. \\ Neeraj Agarwal ${ }^{18} \cdot$ James N. Lowder $^{19} \cdot$ Hong Hua $^{20} \cdot$ Sandra Aung ${ }^{20,21} \cdot$ Janice P. Dutcher $^{22}$
}

Received: 27 October 2015 / Accepted: 29 September 2016 / Published online: 6 October 2016

(C) The Author(s) 2016. This article is published with open access at Springerlink.com

\begin{abstract}
High-dose interleukin-2 (HD IL-2) was approved for treatment of metastatic renal cell carcinoma (mRCC) in 1992 and for metastatic melanoma (mM) in 1998, in an era predating targeted therapies and immune checkpoint inhibitors. The PROCLAIM ${ }^{\mathrm{SM}}$ registry was established to collect and analyze data for patients treated with HD IL-2 in the current era. This analysis includes 170 patients with $\mathrm{mM}$ and 192 patients with mRCC treated between 2005 and 2012 with survival data current as of July 27, 2015. For patients with $\mathrm{mM}$, complete response (CR) was observed in
\end{abstract}

The data have been presented in part at the 50th Annual Meeting of the American Society of Clinical Oncology, May 30-June 3, 2014, Chicago, Illinois, USA, and appear in complete form for the first time in this paper.

Electronic supplementary material The online version of this article (doi:10.1007/s00262-016-1910-x) contains supplementary material, which is available to authorized users.

\section{Janice P. Dutcher}

jpd4401@aol.com

University of Michigan, Ann Arbor, MI, USA

2 Moores Cancer Center, University of California San Diego, La Jolla, CA, USA

3 University of Southern California, Los Angeles, CA, USA

4 Present Address: M.D. Anderson Cancer Center, Houston, TX, USA

5 Rutgers Cancer Center Institute of New Jersey, New Brunswick, NJ, USA

6 Duke University Medical Center, Durham, NC, USA

7 Beth Israel Deaconess Medical Center, Boston, MA, USA

8 Loyola University Medical Center, Maywood, IL, USA

9 St. Luke's University Health Network and Temple University, Bethlehem, PA, USA
$5 \%$, partial response (PR) in $10 \%$, stable disease (SD) in $22 \%$, and $63 \%$ had progressive disease (PD). The median overall survival (mOS) for these patients was 19.6 months, with a median follow-up of 43.1 months. The mOS was not reached for patients achieving CR or PR, and was 33.4 months for patients with SD. For patients with mRCC, $6 \%$ achieved CR, $9 \%$ had PR, $22 \%$ had SD, and $62 \%$ had PD. The mOS was 41 months, with a median followup of 46.6 months. The mOS for patients who had CR and PR was not reached and was 49.6 months for patients with SD. There were no treatment-related deaths among 362 patients. The duration of $\mathrm{mOS}$ for patients with $\mathrm{mM}$ and $\mathrm{mRCC}$ is longer than historically reported. These data support a continued role for IL-2 in the treatment of eligible patients with $\mathrm{mM}$ or $\mathrm{mRCC}$ and warrant further evaluation of HD IL-2 in combination or sequence with other therapeutic agents.

10 Hematology/Oncology Clinic, Baton Rouge, LA, USA

11 Indiana University Simon Cancer Center, Indianapolis, IN, USA

12 Nebraska Cancer Specialists, Omaha, NE, USA

13 Providence Portland Medical Center, Portland, OR, USA

14 Hillman Cancer Center Research, University of Pittsburgh Cancer Institute, Pavillion L1 32c, Pittsburgh, PA, USA

15 University of Colorado Cancer Center, Aurora, CO, USA

16 Levine Cancer Institute, Charlotte, NC, USA

17 Moffitt Cancer Center, Tampa, FL, USA

18 Huntsman Cancer Institute, University of Utah, Salt Lake City, UT, USA

19 Astex Pharmaceuticals, Pleasanton, CA, USA

20 Prometheus Laboratories Inc., San Diego, CA, USA 
Keywords Immunotherapy $\cdot$ Melanoma $\cdot$ Renal cell carcinoma $\cdot$ Interleukin-2

$\begin{array}{ll}\text { Abbreviations } \\ \text { CBR } & \text { Clinical benefit rate } \\ \text { CI } & \text { Confidence interval } \\ \text { CR } & \text { Complete response } \\ \text { CTLA-4 } & \text { Cytotoxic T lymphocyte antigen } 4 \\ \text { ECOG PS } & \text { Eastern Cooperative Oncology Group perfor- } \\ & \text { mance status } \\ \text { HD IL-2 } & \text { High-dose interleukin-2 } \\ \text { LLN } & \text { Lower limit of normal } \\ \text { MAPK } & \text { Mitogen-activated protein kinase } \\ \text { mM } & \text { Metastatic melanoma } \\ \text { mOS } & \text { Median overall survival } \\ \text { mRCC } & \text { Metastatic renal cell carcinoma } \\ \text { mTOR } & \text { Mechanistic target of rapamycin } \\ \text { ORR } & \text { Objective response rate } \\ \text { PD } & \text { Progressive disease } \\ \text { PD-1 } & \text { Programmed cell death receptor-1 } \\ \text { PR } & \text { Partial response } \\ \text { RECIST } & \text { Response evaluation criteria in solid tumors } \\ \text { SD } & \text { Stable disease } \\ \text { TT } & \text { Targeted therapy } \\ \text { ULN } & \text { Upper limit of normal } \\ \text { VEGF } & \text { Vascular endothelial growth factor } \\ \text { WHO } & \text { World Health Organization } \\ & \end{array}$

\section{Introduction}

Historically, treatment options for patients with metastatic melanoma ( $\mathrm{mM}$ ) and metastatic renal cell carcinoma (mRCC) were limited and the prognosis was poor with 5-year overall survival (OS) of 5-10\%, respectively [1]. The finding that some patients with these malignancies responded to highdose interleukin-2 (HD IL-2) ultimately led to Food and Drug Administration (FDA) approval of HD IL-2 for mRCC in 1992 and then for $\mathrm{mM}$ in 1998. The historical response rates and overall survival reported at the time of approval were $16 \%$ and 11.4 months for $\mathrm{mM}$ and $15 \%$ and 16.3 months for mRCC, respectively [2-4]. The trials that led to FDA approval were single arm, uncontrolled studies and early on were associated with significant therapy-related deaths, 2 and $4 \%$, respectively, in melanoma and renal cell carcinoma. They were not analyzed for the survival impact of stable disease.

Recent studies have reported improved survival for patients with both malignancies treated with HD IL-2, with

21 Present Address: Nektar Therapeutics, San Francisco, CA, USA

22 Cancer Research Foundation, Chappaqua, NY, USA reduced treatment-related mortality and a survival benefit associated with stable disease. A retrospective analysis performed at Providence Portland Cancer Center, which included $314 \mathrm{mM}$ and $186 \mathrm{mRCC}$ patients treated between 1997 and 2012, reported an objective response rate (ORR) of $28 \%$ for $\mathrm{mM}$ and $24 \%$ for mRCC patients [5]. In a study of $88 \mathrm{mRCC}$ patients treated at Roswell Park between 2004 and 2011, the observed mOS was 35.5 months compared to historical reference range of 16-20 months [6]. In a prospective multicenter study conducted by the Cytokine Working Group, researchers reported an ORR of $25 \%$ and mOS of 42.8 months in $120 \mathrm{mRCC}$ patients treated between 2006 and 2009 [7]. Thus, the contemporary experience with HD IL-2 suggests improved overall response rate and survival in $\mathrm{mM}$ and $\mathrm{mRCC}$ compared to the historical data.

Following the initial observation of durable long-term benefit from HD IL-2, novel immunotherapies and targeted therapies (TT) have been developed for the treatment of both $\mathrm{mM}$ and $\mathrm{mRCC}$. Immune checkpoint inhibitors directed against cytotoxic T lymphocyte antigen 4 (CTLA4) such as ipilimumab [2011] [8,9] or programmed cell death receptor-1 (PD-1) such as nivolumab [2014 for melanoma, 2015 for mRCC] and pembrolizumab [2014] [10-13] have demonstrated objective responses and durable remissions in $\mathrm{mM}$ and $\mathrm{mRCC}$. In parallel with these advances in immunotherapy, the ability to target drivers of the mitogen-activated protein kinase (MAPK) pathway (vemurafenib [2011], dabrafenib [2013], trametinib [2013], cobimetinib [2015]) led to potential treatments for a genetically defined subset of the $\mathrm{mM}$ population [14-17]. For $\mathrm{mRCC}$, inhibitors of the vascular endothelial growth factor (VEGF) pathway (axitinib [2012], sorafenib [2005], sunitinib [2006], bevacizumab [2009], pazopanib [2009] and cabozantinib [2016]) and inhibitors of the mammalian target of rapamycin (mTOR) pathway (temsirolimus [2007] and everolimus [2009]) have been approved [1821]. Checkpoint inhibitors are effective as monotherapy in approximately $25 \%$ of advanced melanoma patients, as yet undefined, and carry the risk of potentially serious toxicities [22, 23]. Molecular-targeted therapies such as vemurafenib show initial high response rates but patients quickly progress due to acquired drug resistance [24-26]. Although treatment options for $\mathrm{mM}$ and $\mathrm{mRCC}$ have increased in number, the optimal combination and sequencing of therapeutic modalities remains an area of intense investigation.

We hypothesized that real-world data describing the experience with HD IL-2 in the contemporary era of checkpoint inhibitors and targeted therapies would better define the relevance of HD IL-2 in the context of these new therapies. In an effort to study the real-world use of HD IL-2, an observational database, termed PROCLAIM ${ }^{\mathrm{SM}}$ (PROLEUKIN $^{\circledR}$ Observational Study to Evaluate the Treatment 
Patterns and Clinical Response in Malignancy) was created in 2011 [27]. PROCLAIM is the largest patient registry in the world collecting data on IL-2 treatment outcomes, prospectively from about 40 enrolled sites. The PROCLAIM registry is designed to generate new hypotheses from retrospective and prospective cohort analyses. Herein, we report survival and outcomes data from the retrospective cohort analysis, from the 16 sites that provided retrospective data, as of July 27, 2015 (patients treated between 2005 and 2012).

\section{Materials and methods}

\section{Patient cohort}

Within the PROCLAIM registry (ClinicalTrials.gov identifier: NCT01415167) [27], established in 2011, retrospective data from de-identified patient cases have been abstracted from existing charts of patients treated with HD IL-2 between January 2005 to February 2012. Sixteen sites participated in the retrospective database. Patients were at least 18 years of age, had a diagnosis of $\mathrm{mM}$ or $\mathrm{mRCC}$, and had received at least 1 dose of HD IL-2. Sites were encouraged to enroll consecutive eligible patients. In the current report, data from 362 patients, including $170 \mathrm{mM}$ and 192 mRCC, were analyzed with the data extraction date of July 27, 2015. Available baseline data from enrolled patients included demographics (sex, age, and race) and clinical disease characteristics [Eastern Cooperative Oncology Group performance status (ECOG PS), disease stage, primary site of metastasis, BRAF mutation status in $\mathrm{mM}$ patients if tested, and prior treatment]. Patient eligibility at each site was confirmed by a study coordinator, and an electronic data capture system was used to record the data. The registry was approved by the Institutional Review Board at all participating sites. All data were subject to quality control procedures. Among retrospectively collected cohort, no consent was obtained, and only survival data were collected in follow-up. Additionally, due to the retrospective nature of data collection and exemption from consent, no information regarding subsequent IL-2 or other therapy post-IL-2 was collected.

\section{Treatment and assessments}

Physicians managed and treated patients per each institution's standard of care and their own clinical judgment. HD IL-2 (Proleukin ${ }^{\circledR}$ ) was administered as an intravenous bolus every $8 \mathrm{~h}$ at a dose of $600,000 \mathrm{IU} / \mathrm{kg}$ or $720,000 \mathrm{IU} /$ $\mathrm{kg}$ as tolerated, with up to 14 consecutive doses over 5 days (1 cycle of therapy). Patients received a second cycle of HD IL-2 after approximately a 9-day rest period, per the discretion of the investigator. Two cycles of HD IL-2 treatment constituted 1 standard course of HD IL-2 therapy. Additional courses were administered per the discretion of the treating physician. The duration of HD IL-2 drug administration was assessed from the time from the start of the first dose of HD IL-2 to the end of the last dose of HD IL-2 including rest periods. Response to HD IL-2 was determined by the investigator using either World Health Organization (WHO) criteria or Response Evaluation Criteria in Solid Tumors (RECIST), depending on the procedures utilized by the individual physician and site. Response was documented after each HD IL-2 treatment course ( 2 cycles) and approximately every 6 months upon conclusion of therapy

\section{Statistical analyses}

All statistical analyses were performed using SAS software version 9.4. Patient characteristics, tumor response, and survival status were determined using data that were extracted on July 27, 2015. Frequency counts and measures of central tendency were performed to provide descriptive statistics. One-year, 2-year, and 3-year survival probabilities were obtained using the Kaplan-Meier product limit method and corresponding confidence interval (CI) were obtained using Greenwood's formula. Kaplan-Meier curves with $95 \%$ CIs were used to estimate mOS, with the log-rank test to determine significance $(P<.05)$. OS was calculated from the date of first dose of HD IL-2 to date of death or date of most recent follow-up. Patients were followed until date of death or until last day of follow-up. Survival estimates for mRCC patients were also analyzed based on stratification into risk groups according to the International mRCC Database Consortium model (Heng criteria) [28]. The parameters included: ECOG PS $\geq 2$, less than 1 year from initial diagnosis to treatment, hemoglobin concentration < lower limit of normal (LLN), calcium concentration $>$ upper limit of normal (ULN), neutrophil count $>$ ULN, and platelet $>$ ULN. Patients were grouped into favorable ( 0 factors), intermediate (1-2 factors), and poor ( 3 or more factors) risk groups based on the number of risk factors.

\section{Results}

\section{Patient population}

Demographic and disease characteristics for both $\mathrm{mM}$ and mRCC patients are listed in Table 1 . There were $91 \%$ $(n=154) \mathrm{mM}$ and $94 \%(n=89) \mathrm{mRCC}$ patients that reported stage IV disease; note that 97 patients did not have tumor stage data available and were not used in this 
Table 1 Patient demographics and disease characteristics

$\begin{array}{llll}\mathrm{mM} & \% & \frac{\mathrm{mRCC}}{n=192} & \%\end{array} \quad \begin{aligned} & \text { Total } \\ & \end{aligned}$

\section{Gender}

Male

Female

70

100

Age

$<65$

$\geq 65$

Median

Range

Race

White

Black

Other

Decline

ECOG $P S^{a}$

0

1

2

Missing $^{\mathrm{a}}$

Stage ${ }^{b}$

IIIc

III/III NOS

IIIb/IVa

IV/IVNOS

M1a

M1b

M1c

Other, specify

Missing ${ }^{\mathrm{b}}$

$149 \quad 8$

21

54

20-79

$\begin{array}{rl}165 & 97 \\ 4 & 2 \\ 1 & 1 \\ 0 & 0\end{array}$

124

44

2

0

8

0

6

36

11

28

79

2

0

1
0

73

1

0

\section{5}

0

4

4

6

1

41

59

144

48

168

24

56

19-74

NA

97

2

26

21

16

46

0

88

12

NA

181
2
7
2

156

34

1

1

NA

2

4

89

NA

NA

NA

NA

97

\section{Had mutation testing}

No

$\mathrm{Yes}^{\mathrm{c}}$

$B R A F+$

$\mathrm{No}^{\mathrm{c}}$

Not tested ${ }^{\mathrm{c}}$

$\mathrm{Yes}^{\mathrm{c}}$

Site of metastasis

Skin, lungs, LNs only

Other including skin, lungs, LNs

Not reported

Prior therapy ${ }^{d}$

Surgery

Radiation

Chemotherapy

Other immunotherapy

Targeted therapy

Blinded RCT

$\begin{array}{rr}112 & 66 \\ 58 & 34 \\ 17 & 30 \\ 1 & 2 \\ 40 & 70\end{array}$

$\begin{array}{lll}75 & 214 & 59 \\ 25 & 148 & 41 \\ 88 & 317 & 88 \\ 13 & 45 & 12 \\ \text { NA } & 55 & \text { NA } \\ \text { NA } & 19-79 & \text { NA }\end{array}$

$94 \quad 346 \quad 96$

1

$1 \quad 6$

$4 \quad 8$

12

2

2

21

$82 \quad 280 \quad 78$

$18 \quad 78 \quad 22$

$1-3$

$1 \quad 1$

$\begin{array}{llll} & \text { NA } & 8 & 3\end{array}$

$\begin{array}{lll}\text { NA } & 8 & 3 \\ 2 & 2 & 1\end{array}$

$\begin{array}{lll}4 & 10 & 4\end{array}$

$94 \quad 125 \quad 47$

NA 11

NA $\quad 28 \quad 11$

NA $\quad 79 \quad 30$

NA $\quad 2 \quad 1$

NA $\quad 97$

mRCC

97

Total

$\begin{array}{lrrr}\text { NA } & \text { NA } & 112 & 31 \\ \text { NA } & \text { NA } & 58 & 16 \\ & & & \\ \text { NA } & \text { NA } & 17 & 30 \\ \text { NA } & \text { NA } & 1 & 2 \\ \text { NA } & \text { NA } & 40 & 70\end{array}$

$\begin{array}{rrrrrr}48 & 28 & 73 & 38 & 121 & 33 \\ 119 & 70 & 79 & 41 & 198 & 55 \\ 3 & 2 & 40 & 21 & 43 & 12\end{array}$

\begin{tabular}{rrllrr}
118 & 69 & 183 & 95 & 301 & 83 \\
49 & 29 & 15 & 8 & 64 & 18 \\
32 & 19 & 5 & 3 & 37 & 10 \\
58 & 34 & 5 & 3 & 63 & 17 \\
3 & 2 & 25 & 13 & 28 & 8 \\
3 & 2 & 3 & 2 & 6 & 2 \\
\hline
\end{tabular}

\section{Springer}


Table 1 continued

\begin{tabular}{lrrrrr}
\hline & $\mathrm{mM}$ & $\mathrm{mRCC}$ & \multicolumn{1}{c}{ Total } & & \\
\hline Other & 3 & 2 & 1 & 1 & 4 \\
Untreated & 34 & 20 & 5 & 3 & 39 \\
\hline
\end{tabular}

${ }^{\text {a }}$ ECOG PS based on patients with available data

${ }^{b}$ Sites were not required to enter in tumor stage for mRCC patients. Calculations were from patients with available data (95). Ninety-seven patients did not have tumor stage data

c BRAF mutation percentage was calculated from patients who had mutation testing

${ }^{\mathrm{d}}$ Patients may have had multiple prior therapies. Percentages were calculated based on number of patients

$N A$ not available, ECOG PS Eastern Cooperative Oncology Group performance status, NOS not otherwise specified, LNs lymph nodes, RCT research clinical trial

Table 2 Summary and time to tumor response

\begin{tabular}{lcrrrrrr}
\hline & Final response & $\%$ & Course 1 & Course 2 & Course 3 & Course 4 & Course 5 \\
\hline $\mathrm{mM} n=(158)^{\mathrm{a}}$ & & & & & & & \\
$\mathrm{CR}$ & 8 & 5 & 2 & 3 & 3 & 0 & 0 \\
$\mathrm{PR}$ & 16 & 10 & 8 & 4 & 4 & 0 & 0 \\
$\mathrm{SD}$ & 34 & 22 & 10 & 13 & 7 & 3 & 1 \\
$\mathrm{PD}$ & 100 & 63 & 82 & 12 & 6 & 0 & 0 \\
$\mathrm{CR}+\mathrm{PR}$ & 24 & 15 & 10 & 7 & 7 & 0 & 0 \\
$\mathrm{CR}+\mathrm{PR}+\mathrm{SD}$ & 58 & 37 & 20 & 20 & 14 & 3 & 1 \\
$\mathrm{mRCC}(n=185)^{\mathrm{a}}$ & & & & & & & \\
$\mathrm{CR}$ & 12 & 6 & 6 & 6 & 0 & 0 & 0 \\
$\mathrm{PR}$ & 17 & 9 & 3 & 11 & 2 & 0 & 1 \\
$\mathrm{SD}$ & 41 & 22 & 23 & 10 & 4 & 4 & 0 \\
$\mathrm{PD}$ & 115 & 62 & 103 & 8 & 4 & 0 & 0 \\
$\mathrm{CR}+\mathrm{PR}$ & 29 & 15 & 9 & 17 & 2 & 0 & 1 \\
$\mathrm{CR}+\mathrm{PR}+\mathrm{SD}$ & 70 & 37 & 32 & 27 & 6 & 4 & 1 \\
\hline
\end{tabular}

${ }^{a}$ Responses are from patients identified after each course of HD IL-2 therapy with a final response calculation. Most patients had an ECOG PS of $0(n=124$, $73 \% \mathrm{mM} ; n=156,82 \% \mathrm{mRCC}$ ). Among the $\mathrm{mM}$ patients, only 57 (34\%) had BRAF mutation testing data available, and in this group, 40 tested positive for the BRAFV600E mutation. There were $58(34 \%) \mathrm{mM}$ patients who had prior immunotherapy and $3(2 \%)$ who had prior targeted therapy. The database collected actual prior therapy, but did not specify whether prior immunotherapy was in the adjuvant setting. Among the mRCC patients, $183(95 \%)$ had a prior nephrectomy and $25(13 \%)$ had received prior targeted therapy. Thus, in this treatment time frame (2005-2012), HD IL-2 was often the initial treatment for eligible advanced $\mathrm{mRCC}$ and $\mathrm{mM}$ patients registered in PROCLAIM.

\section{IL-2 administration}

The duration of HD IL-2 drug exposure was assessed from the start of the first dose of HD IL-2 to the end of the last dose of HD IL-2 including the rest period. For censored patients (patients still alive), the median duration of HD IL-2 drug exposure including the rest period was 2.4 months (range 0.56-14.37) and 0.66 months (range $0.06-12.99)$ for $\mathrm{mM}(n=43)$ and $\mathrm{mRCC}(n=89)$, respectively. Melanoma patients more frequently received additional courses (Supplementary Table 1). For all patients with $\mathrm{mM}(n=170)$, the median duration of HD IL-2 drug exposure was 0.84 months (range 0.10-14.37), and for all patients with $\mathrm{mRCC}(n=192)$, the median duration was 0.62 months (range 0.03-12.99). The number of doses of IL-2 per cycle for $\mathrm{mM}$ and $\mathrm{mRCC}$ are described in Supplementary Table 1 and were no different from current practice or recent clinical trials and clinical reports $[5,7]$.

\section{Tumor response}

Response data were available for 158 patients $(93 \%)$ with mM: Eight patients (5\%) achieved CR, $16(10 \%)$ had PR, and $34(22 \%)$ had SD, while 100 (63\%) had progressive 
disease (PD) (Table 2). The objective response rate (ORR), defined as $\mathrm{CR}+\mathrm{PR}$, was $15 \%$, and the clinical benefit rate (CBR), defined as $\mathrm{CR}+\mathrm{PR}+\mathrm{SD}$, was $37 \%$. For patients with $\mathrm{mRCC}$, data were available for $185(96 \%)$ patients. There were $12(6 \%)$ patients with CR, 17 (9\%) with PR, $41(22 \%)$ with SD, and $115(62 \%)$ with PD (Table 2). The ORR in patients with $\mathrm{mRCC}$ was $15 \%$, and clinical benefit was observed in 70 (37\%) patients. CR, PR, or SD were frequently determined after course 2 of HD IL-2 treatment ( $\geq 62 \%$ in $\mathrm{mM}$ and $>80 \%$ in mRCC), while $82 \%$ of $\mathrm{mM}$ and $90 \%$ of mRCC patients with PD were identified after course 1 of treatment (Table 2). Therefore, the efficacy of IL-2 can be determined in a relatively short period. Response rates were also analyzed based on prior treatment. Therapies prior to IL-2 are listed in Supplementary Table 2. Seventy-seven melanoma patients and 30 RCC patients received prior therapy, and this could have been in the adjuvant setting. No further details have been recorded. Some clearly received prior treatment for advanced disease. The majority of these patients received 1 or 2 prior therapies (Supplementary Tables 3, 4). In this database, there were no responses to IL-2 in patients who had 3 or more prior therapies.

\section{Survival data}

Survival estimates were calculated from the first dose of HD IL-2. For mM patients, the mOS was 19.6 months [95\% confidence interval (CI): 14.04, 24.10] with a median follow-up of 43.1 months (95\% CI 37.61, 46.13) (Fig. 1a). The mOS was not yet reached for those who experienced CR $(n=8)$ and PR $(n=16)$ (Fig. 1b). A statistically significant difference in mOS was observed between the patients who experienced SD and those who had PD (33.4 vs. 13.2 months; $P<.0001$ ) (Fig. 1b). There was no statistically significant difference in mOS between patients who experienced SD and PR. The 1-, 2-, and 3-year survival rates for patients with CR/PR were 91,78 , and $68 \%$, respectively. The 1-, 2-, and 3-year survival rates for patients with SD were 82, 73, and $47 \%$, respectively. An analysis of survival in patients who were systemic therapynaïve versus those with prior systemic therapy was performed in the $\mathrm{mM}$ cohort. Prior systemic therapy included chemotherapy, targeted therapy, and/or immunotherapy. The mOS for patients without prior systemic therapy was 20.0 months $(n=93)$ compared to 18.7 months $(n=77)$ for those with prior systemic therapy $(P=.76$, Supplementary Figure 1a).

The mOS for patients with mRCC was 41 months (95\% CI 32.6, 57.5) with a median follow-up of 46.6 months (95\% CI 41.8, 49.6) (Fig. 1c). Patients with CR $(n=12)$ and PR $(n=17)$ had not reached a median overall survival, while patients with SD $(n=41)$ had a mOS of 49.6 months
(Fig. 1d). There was no statistically significant difference in mOS between patients who experienced SD and PR. Patients with PD $(n=115)$ experienced a mOS of 32.6 months (Fig. 1d). There was a significant difference in mOS between the patients who experienced SD and those who had PD (49.6 vs. 32.6 months; $P=.01$ (Fig. 1d). The $1-, 2-$, and 3-year survival rates for patients with CR/PR were 94,84 , and $77 \%$, respectively. The 1-, 2-, and 3-year survival rates for patients with SD were 93,72 , and $63 \%$, respectively. An analysis of survival in patients who were systemic therapy-naïve versus those with prior systemic therapy was performed in the mRCC cohort. The mOS for patients without prior systemic therapy was 48.9 months $(n=162)$ compared to 16.4 months $(n=30)$ for those with prior systemic therapy $(P=.03$, Supplementary Fig. 1b).

There were no reported investigator assessed treatmentrelated deaths for patients with $\mathrm{mM}$ or $\mathrm{mRCC}(N=362)$.

\section{BRAF mutation status for $\mathrm{mM}$ patients}

$B R A F$ mutation testing was performed in only 57 of the total 170 melanoma patients. The mOS was 25.2 months for patients with BRAFV600E mutation $(n=40)$ and was 11.6 months for $B R A F$ wild-type patients $(n=17)$ (data not shown). Of the patients with data available for response to IL-2, among those with $B R A F$ mutation there were no CRs, 2 PR, 11 SD, and $25 \mathrm{PD}$, (data not shown). Among the $B R A F$ wild-type patients, there were $3 \mathrm{CR}, 2 \mathrm{PR}, 1$ $\mathrm{SD}$, and $9 \mathrm{PD}$. However, because the proportion of patients tested is a small subset, this data are provided for completeness only.

\section{Survival by risk factors for $\mathrm{mRCC}$}

To determine OS based on externally validated prognostic risk factors for $\mathrm{mRCC}$, patients were stratified into risk groups using the international mRCC Database Consortium model, also known as the Heng Criteria [28]. One hundred and forty-nine patients (78 \%) had complete data for all six parameters and were included in this analysis. Thirtyseven patients $(25 \%)$ were in the favorable-risk group, 95 patients $(64 \%)$ were in the intermediate-risk group, and 17 patients $(11 \%)$ were in the poor-risk group. The mOS for patients in the favorable-risk group was 63.7 months, while for patients in the intermediate- and poor-risk groups, the mOS was 34.3 and 18.4 months, respectively (Table 3, $P=.054$ favorable vs. intermediate, $P=.001$ favorable vs. poor, $P=1.0$ intermediate vs. poor). An analysis of response to HD IL-2 for the three risk groups was also performed (Table 3). For patients in the favorable group, there were $2 \mathrm{CR}, 1 \mathrm{PR}, 9 \mathrm{SD}$, and $25 \mathrm{PD}$. In the intermediate group, there were $9 \mathrm{CR}, 4 \mathrm{PR}, 17 \mathrm{SD}$ and $60 \mathrm{PD}$. In the poor-risk group, there were $0 \mathrm{CR}, 3 \mathrm{PR}, 5 \mathrm{SD}$ and 7 


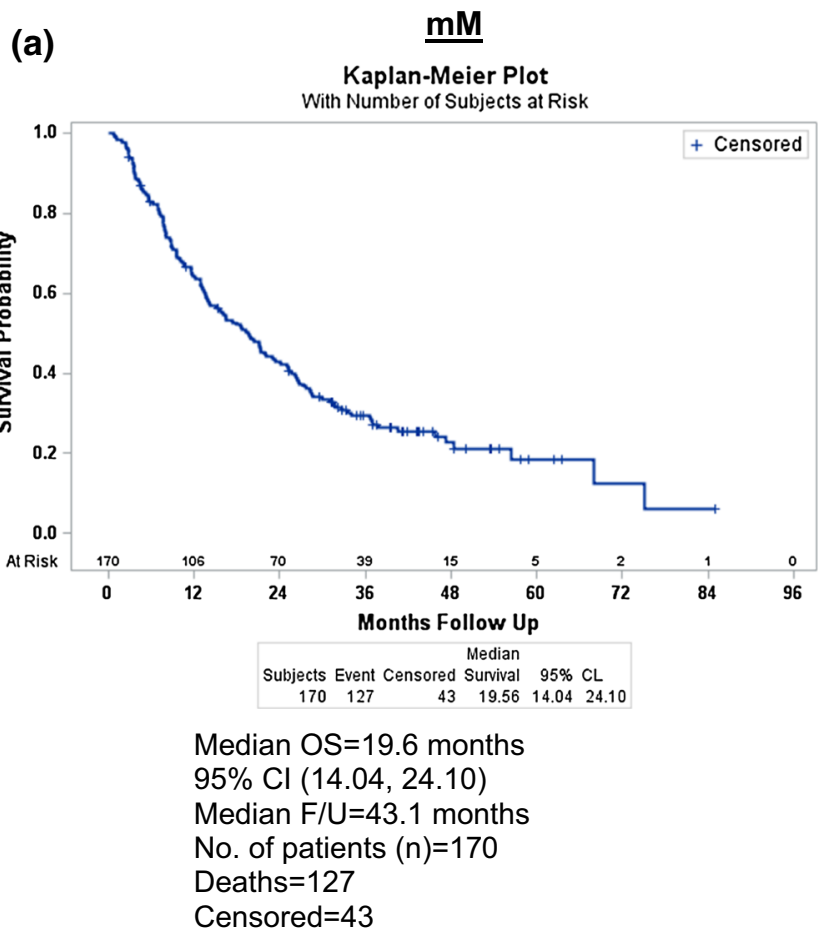

(b)

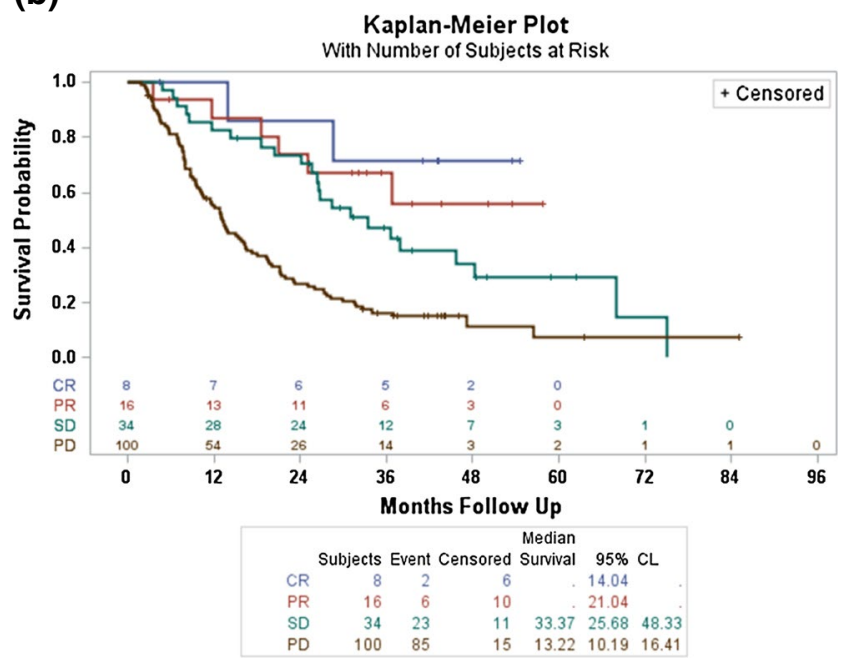

$$
\begin{aligned}
& \mathrm{CR}, \mathrm{n}=8, \mathrm{mOS}=\mathrm{NR} \\
& \mathrm{PR}, \mathrm{n}=16, \mathrm{mOS}=\mathrm{NR} \\
& \mathrm{SD}, \mathrm{n}=34, \mathrm{mOS}=33.4 \\
& \mathrm{PD}, \mathrm{n}=100, \mathrm{mOS}=13.2 \\
& P<.0001 \mathrm{SD} \text { vs. } \mathrm{PD} \\
& P>.05 \mathrm{SD} \text { vs. } \mathrm{PR}
\end{aligned}
$$

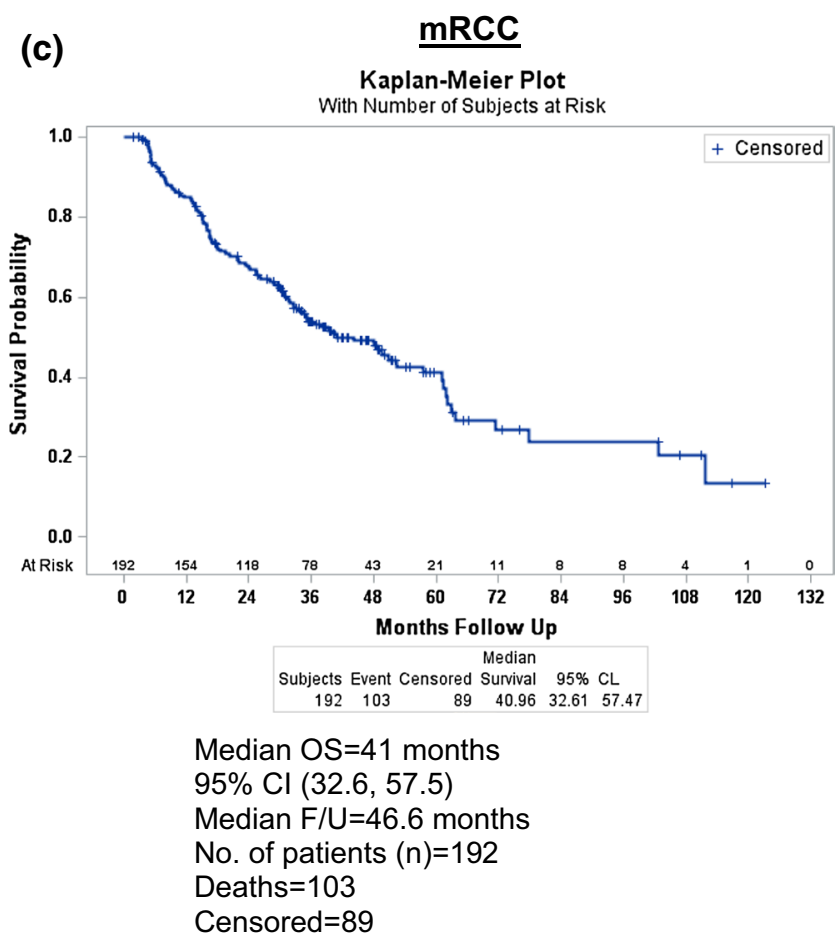

(d)

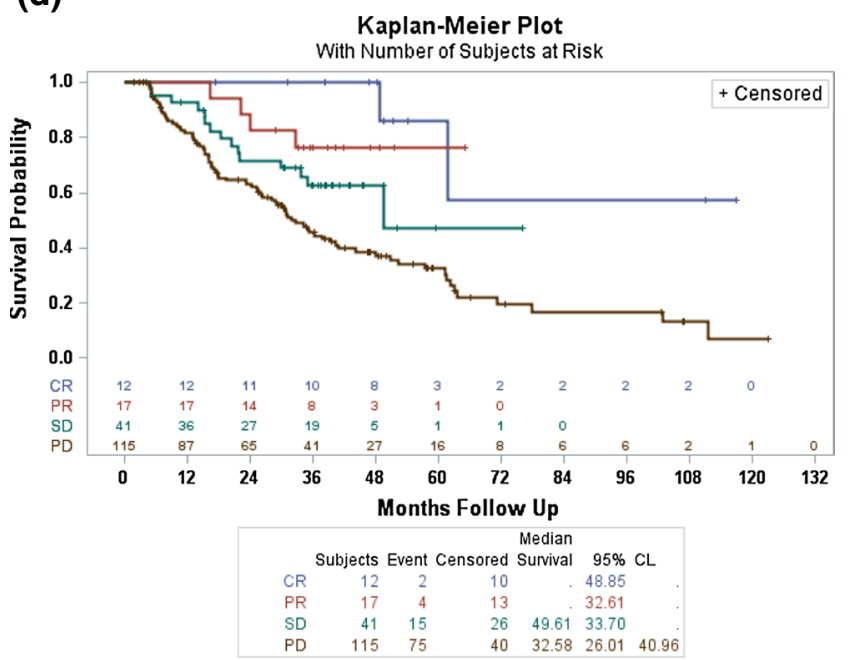

$\mathrm{CR}, \mathrm{n}=12, \mathrm{mOS}=\mathrm{NR}$

$\mathrm{PR}, \mathrm{n}=17, \mathrm{mOS}=\mathrm{NR}$

$\mathrm{SD}, \mathrm{n}=41, \mathrm{mOS}=49.6$

$\mathrm{PD}, \mathrm{n}=115, \mathrm{mOS}=32.6$

$P=.01$ SD vs. PD
$P>.05$ SD vs. PR

Fig. 1 Overall survival in patients treated with HD IL-2 a Median OS (mM). b Median OS by response (mM). c Median OS (mRCC). d Median OS by response (mRCC). Vertical bars represent censored subjects. NR, not reached; F/U, follow-up

PD. Additionally, survival by risk category is presented in Table 3, with data from the Heng report [28] (targeted therapy) and the first Motzer report [29] (interferon therapy) provided for reference.

\section{Survival by time of HD IL-2 treatment}

Although no data are available on post-IL-2 treatments, we have post hoc evaluated survival among cohorts of patients 
Table 3 Survival and response of mRCC to IL-2 (PROCLAIM) by Heng criteria

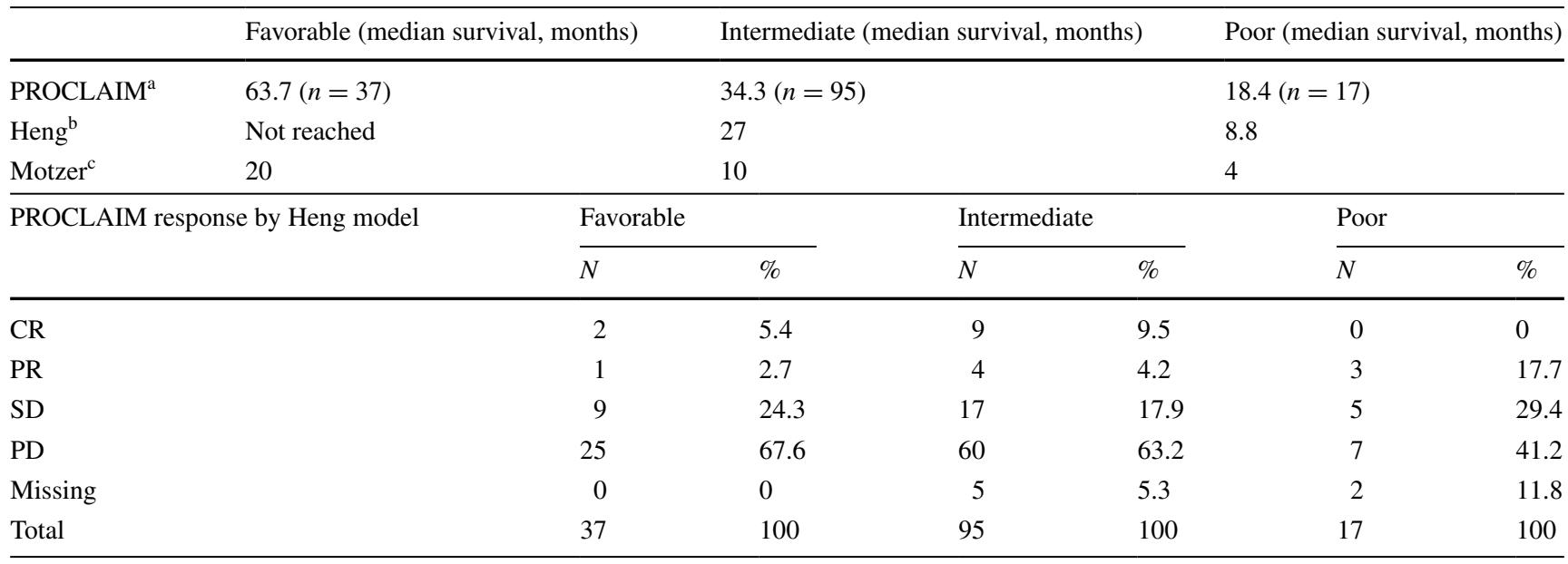

Responses were based on patients with available data

a PROCLAIM median follow-up was 46.6 months

b Heng DY et al., JCO 2009, 27(34): 5794-9. Median follow-up was 24.5 months

${ }^{c}$ Motzer RJ et al., JCO 1999, 17(8): 2530-40. Median follow-up was 33 months

treated with HD IL-2 in the early years of the retrospective registry (2005-2009) and the later years (2010-2012), when more subsequent therapies were available. As can be seen in Fig. 2a, b, for mM and in Fig. 2c, d for mRCC, the survival is very similar.

\section{Discussion}

The PROCLAIM observational database informs upon the real-world use and outcome of HD IL-2 for $\mathrm{mM}$ and $\mathrm{mRCC}$ patients in the era of TT and checkpoint immunotherapy. This retrospective analysis of contemporary patients with $\mathrm{mM}$ and $\mathrm{mRCC}$ receiving HD IL-2 revealed improved median overall survival compared to the historical experience. Single institution reports of IL-2 treated patients also show improvement in OS compared to historical experience $[5,30]$ as has a prospective multi-institutional study in mRCC (SELECT) [7]. Therefore, the PROCLAIM observational database demonstrates consistency with these reports [31, 32].

In this report, data were included from patients treated between 2005 and 2012, and even so, many of these patients received HD IL-2 as their initial treatment for advanced disease ( $\mathrm{mM}$ no prior systemic treatment, $N=93$; prior systemic treatment, $N=77$; mRCC no prior systemic treatment, $N=162$, prior systemic treatment, $N=30$ ). However, they were treated during a transition period in which new agents were in development in clinical trials in both mRCC and $\mathrm{mM}$, and eventually commercially, providing options for follow-on treatment. The clinical trials available to these patients in that era were either for patients who had progressed on prior treatment, or for newly diagnosed patients. Eventually, commercial drugs were available for patients with $\mathrm{mRCC}$ (2006) and for $\mathrm{mM}$ (2011).

As has been noted in clinical trials of the newer targeted therapies and more recently checkpoint inhibitors, survival of patients with advanced disease has improved, and patients are able to receive multiple sequential treatments with different mechanisms of action. Importantly, $43 \%$ of HD IL-2-treated patients in this retrospective cohort achieved SD as best response. We have evaluated the outcome of treatment with HD IL-2 by best response and have observed prolonged $\mathrm{OS}$ in patients with $\mathrm{SD}$, compared to patients with PD (Fig. 1b, d). We are exploring the potential impact of SD on OS as a consequence of HD IL-2 therapy in our prospective cohort versus simply the effect of follow-on therapy.

Because the data presented here reflect a retrospectively collected database, we do not have specific data on the treatment(s) patients received post-IL-2 progression. However, we have evaluated OS in the group treated with HD IL-2 between 2005 and 2009 versus between 2010 and 2012 , possibly indicating that more subsequent therapy was available in the later time frame, but without information regarding the subsequent treatment of the patients in this retrospective cohort. As can be seen from Fig. 2a, b for melanoma and Fig. 2c, d for renal cell cancer, there is no significant difference in OS between the two time periods. This is surprising given the expected increased access to subsequent therapy in the later years. However, this information is derived from a retrospective database and could reflect selection bias of patients entered, small numbers in 

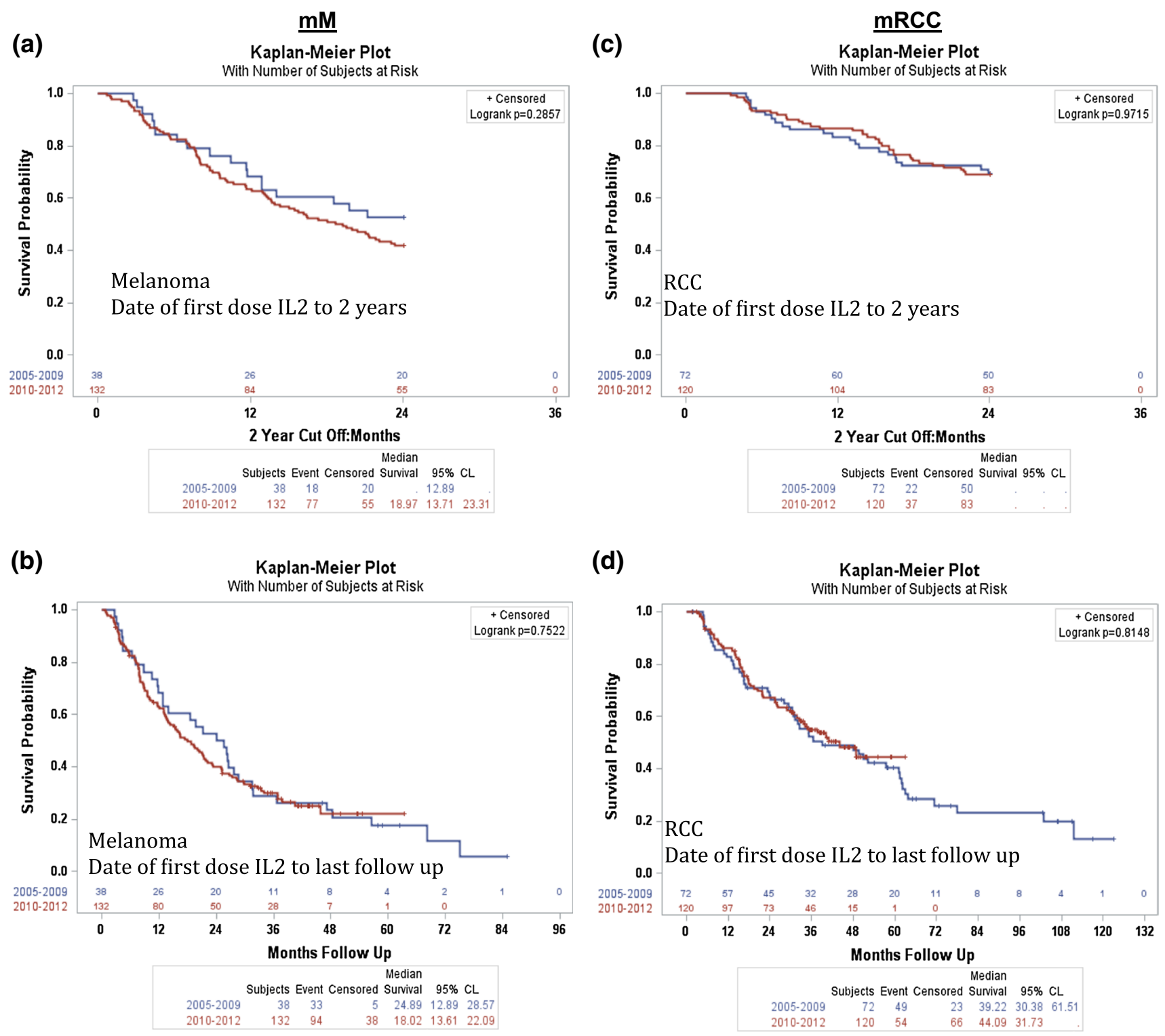

Fig. 2 In order to determine the effect of targeted therapies on survival, patients were grouped into 2 cohorts based on years prior to or post targeted therapy approval (1 cohort from 2005-2009 and 1 cohort from 2010-2012). a Median OS for mM patients from date of

the earlier group, or possibly an effect of HD IL-2 on both groups. This will need to be the subject of future investigations, and no conclusions can be drawn from this dataset.

This retrospective cohort analysis provides a means of generating hypotheses to test in prospectively collected patient treatment records, which is ongoing. A major focus of the prospective PROCLAIM database is to evaluate the safety and efficacy of sequential treatments for mRCC and $\mathrm{mM}$, and data on all treatment modalities are being collected, both prior and follow-on treatment. We will continue to evaluate the impact of SD on long-term outcome, as well as the potential for synergy among immunotherapy first dose of IL-2 with a 2 year cutoff. b Median OS in mM patients from first dose of IL-2 to the last follow-up. c Median OS for mRCC patients from date of first dose of IL-2 with a 2 year cutoff. d Median OS in mRCC patients from first dose of IL-2 to the last follow-up

treatments. We will also evaluate the safety and efficacy of administration of HD IL-2 subsequent to the newer targeted and immunotherapy approaches.

Additional analyses of this retrospective cohort include an evaluation of the effect of prior therapy on outcome from IL-2. As noted in Supplementary Figure 1, there was a significant effect among patients with $\mathrm{mRCC}$, but not significant among patients with $\mathrm{mM}$. In part, this may be because much of the prior systemic treatment for $\mathrm{mM}$ was interferon and it was likely (not documented in the database) given as adjuvant therapy. However, this could also reflect a negative impact of prior therapy (mostly targeted therapy $-N=25$ patients with 
prior targeted therapy) on outcome for patients with $\mathrm{mRCC}$. Both of these hypotheses provide additional questions to pose from the PROCLAIM prospective cohort, and these analyses will be available with more detail from that cohort.

Although data on B-RAF mutation status were collected, it was not available for two-thirds of the subjects. Therefore, analysis of IL-2 outcome based on mutational status is only exploratory and will require prospective collection of this information. To date, there has been no evidence that B-RAF mutation status impacts the clinical response to HD IL-2 treatment.

Among the mRCC patients, prognostic subgroup information was evaluated, and in Table 3 we provide the response data to HD IL-2 by subgroup. Surprisingly, all subgroups have evidence of major response. Additionally, in Table 3, we have delineated the overall survival among the patients in this retrospective cohort by prognostic group alongside the results from the original reports by Heng et al. [28] of the factors among targeted therapy-treated patients and the original Motzer et al. [29] report in patients treated with interferon. It is gratifying to see that there is continued survival improvement over time with each successive report.

In summary, we report an analysis of a retrospectively accrued cohort from the PROCLAIM observational database of real-world patients treated in the modern era of HD IL-2 (2005-2012). We have demonstrated that these patients received similar dosing of HD IL-2 compared to clinical trials and that patient demographics reflect prior reports of these populations. Prior therapy may have an impact on outcome of mRCC patients subsequently treated with HD IL-2, compared with melanoma patients. Alternatively much of the prior therapy for the melanoma patients may have been in the adjuvant setting, such that prior treatment did not impact on effect of HD IL-2. Finally, patients achieving SD after IL-2 had improved OS compared to PD patients, as was also noted in the prospective IL-2 SELECT RCC trial [7]. We are evaluating the outcome of SD patients prospectively, and we are investigating the impact of sequential therapy and when these are given in the course of the disease (at SD or PD) among all IL-2 treated patients in the prospective cohort of the PROCLAIM observational database.

\footnotetext{
Acknowledgments The PROCLAIM ${ }^{\mathrm{SM}}$ clinical registry is funded by Prometheus Laboratories Inc. From Prometheus Laboratories Inc., we thank Theresa Luna for ensuring timely entry of data and querying sites in the event of a data anomaly and Jessica Perritt for biostatistical analysis. The authors thank the study coordinators at each site for entering patient data.
}

Funding The PROCLAIM clinical registry is funded by Prometheus Laboratories Inc.

\section{Compliance with ethical standards}

Conflict of interest M. Wong, J. Clark, D. McDermott, H. Kaufman, G. Daniels, M. Morse, and J. Dutcher, author(s) of this publication serve as consultants for Prometheus Laboratories Inc., which markets the product related to the research being reported. A. Alva served as an advisory board member for Bayer, Eisai and Prometheus and has received research funding from Bayer, Genentech, Novartis, SanofiAventis, BMS, and Prometheus. H. Kaufman has received honoraria from Alkermes, Amgen, EMD Serono, Merck, Prometheus and Sanofi; served as an advisory board member at Prometheus and consultant for Alkermes, Amgen, EMD Serono, Merck and Sanofi; and served on the Merck Speaker's Bureau. A. Morse has received honoraria from Genentech, Prometheus, Celgene, Ipsen, Novartis, and Lexxicon; has served as an advisory board member for Genentech, Prometheus, Celgene, Ipsen, Novartis, and Lexxicon; and served on the speaker's board of Genentech, Prometheus, Celgene, and Novartis. J. Clark has received honoraria from Prometheus, BMS, Pfizer and Merck; has served as an advisory board member for Prometheus and Bayer-Onyx; and served on the speaker's bureau for Prometheus, BMS and Merck. R. Hauke has received honoraria from Best Doctors for second opinion consultations. B. Curti has received honoraria from Prometheus; is an unpaid consultant for Agonox and Ubivac; served on the speaker's bureau for Prometheus; has research support from Prometheus and Galectin Therapeutics; and received travel reimbursement from Agonox, BMS and Prometheus. R. Gonzalez has served as advisory board member for Bayer-Onyx, BMS, Genentech, GSK, Prometheus, Roche; has received research funding from Bayer, BMS, Eisai, Genentech, GSK, Merck, Novartis, Pfizer, Prometheus, Roche. M. Fishman has Research support in RCC-related trials from Acceleron, Altor, Aveo, Bayer, Eisai, Exelixis, GSK (now part of Novartis), Merck, Pfizer, Prometheus, Tracon; and participated in RCC-related advisory boards for Aveo, Bayer, Eisai, GSK (now part of Novartis), Novartis, Pfizer, Prometheus. T. Logan has served as consulting or advisory role for Argos, Aveo, Bristo Myers Squibb, Celgene, Genentech, GlaxoSmithKline, Novartis, Pfizer, Prometheus, Wyeth; is on speaker's bureau for BMS, GSK, Novartis, Pfizer, Prometheus; and has research funding from Abbott Labs, Abraxis, Acceleron, Amgen, Argos, AstraZeneca, Aveo, Biovex, BMS, Eisai, Eli Lilly, GSK, Hoffman-LaRoche, Immatics, Merck, Novartis, Pfizer, Prometheus, Roche, Synta, Threshold Pharmaceuticals, Millenium, Tracon, Cerulean, EMD Serono. JP Dutcher serves on speaker's bureaus for Prometheus, Novartis, Pfizer; serves as consultant to Prometheus, Nektar, Lion; serves on data safety and monitoring boards for BMS, Tracon, PrECOG. H. Hua is an employee of Prometheus Laboratories Inc. S. Aung was an employee of Prometheus Laboratories Inc. and is currently an employee of Nektar Therapeutics. All other authors declare no conflict of interest.

Ethical approval All procedures performed in studies involving human participants were in accordance with the ethical standards of the institutional and/or national research committee and with the 1964 Helsinki declaration and its later amendments or comparable ethical standards. For this type of study formal consent is not required.

Open Access This article is distributed under the terms of the Creative Commons Attribution 4.0 International License (http://creativecommons.org/licenses/by/4.0/), which permits unrestricted use, distribution, and reproduction in any medium, provided you give appropriate credit to the original author(s) and the source, provide a link to the Creative Commons license, and indicate if changes were made. 


\section{References}

1. Siegel R, Naishadham D, Jemal A (2013) Cancer statistics, 2013. CA Cancer J Clin 63:11-30

2. Fyfe G, Fisher RI, Rosenberg SA, Sznol M, Parkinson DR, Louie AC (1995) Results of treatment of 255 patients with metastatic renal cell carcinoma who received high-dose recombinant interleukin-2 therapy. J Clin Oncol 13:688-696

3. Atkins MB, Lotze MT, Dutcher JP, Fisher RI, Weiss G, Margolin K, Abrams J, Sznol M, Parkinson D, Hawkins M, Paradise C, Kunkel L, Rosenberg SA (1999) High-dose recombinant interleukin 2 therapy for patients with metastatic melanoma: analysis of 270 patients treated between 1985 and 1993. J Clin Oncol 17:2105-2116

4. Fisher RI, Rosenberg SA, Fyfe G (2000) Long-term survival update for high-dose recombinant interleukin-2 in patients with renal cell carcinoma. Cancer J Sci Am 6(Suppl 1):S55-S57

5. Payne R, Glenn L, Hoen H, Richards B, Smith JW 2nd, Lufkin R, Crocenzi TS, Urba WJ, Curti BD (2014) Durable responses and reversible toxicity of high-dose interleukin-2 treatment of melanoma and renal cancer in a Community Hospital Biotherapy Program. J Immunother Cancer 2:2-13

6. Hanzly M, Aboumohamed A, Yarlagadda N, Creighton T, Digiorgio L, Fredrick A, Rao G, Mehedint D, George S, Attwood K, Kauffman E, Narashima D, Khushalani NI, Pili R, Schwaab T (2014) High-dose interleukin-2 therapy for metastatic renal cell carcinoma: a contemporary experience. Urology 83:1129-1134

7. McDermott DF, Cheng SC, Signoretti S, Margolin KA, Clark JI, Sosman JA, Dutcher JP, Logan TF, Curti BD, Ernstoff MS, Appleman L, Wong MK, Khushalani NI, Oleksowicz L, Vaishampayan UN, Mier JW, Panka DJ, Bhatt RS, Bailey AS, Leibovich BC, Kwon ED, Kabbinavar FF, Belldegrun AS, Figlin RA, Pantuck AJ, Regan MM, Atkins MB (2015) The high-dose aldesleukin "select" trial: a trial to prospectively validate predictive models of response to treatment in patients with metastatic renal cell carcinoma. Clin Cancer Res 21:561-568

8. Hodi FS, O'Day SJ, McDermott DF, Weber RW, Sosman JA, Haanen JB, Gonzalez R, Robert C, Schadendorf D, Hassel JC, Akerley W, van den Eertwegh AJ, Lutzky J, Lorigan P, Vaubel JM, Linette GP, Hogg D, Ottensmeier CH, Lebbe C, Peschel C, Quirt I, Clark JI, Wolchok JD, Weber JS, Tian J, Yellin MJ, Nichol GM, Hoos A, Urba WJ (2010) Improved survival with ipilimumab in patients with metastatic melanoma. N Engl J Med 363:711-723

9. Robert C, Thomas L, Bondarenko I, O’Day S, Weber J, Garbe C, Lebbe C, Baurain JF, Testori A, Grob JJ, Davidson N, Richards J, Maio M, Hauschild A, Miller WH Jr, Gascon P, Lotem M, Harmankaya K, Ibrahim R, Francis S, Chen TT, Humphrey R, Hoos A, Wolchok JD (2011) Ipilimumab plus dacarbazine for previously untreated metastatic melanoma. N Engl J Med $364: 2517-2526$

10. Topalian SL, Sznol M, McDermott DF, Kluger HM, Carvajal RD, Sharfman WH, Brahmer JR, Lawrence DP, Atkins MB, Powderly JD, Leming PD, Lipson EJ, Puzanov I, Smith DC, Taube JM, Wigginton JM, Kollia GD, Gupta A, Pardoll DM, Sosman JA, Hodi FS (2014) Survival, durable tumor remission, and long-term safety in patients with advanced melanoma receiving nivolumab. J Clin Oncol 32:1020-1030

11. Hamid O, Robert C, Daud A, Hodi FS, Hwu WJ, Kefford R, Wolchok JD, Hersey P, Joseph RW, Weber JS, Dronca R, Gangadhar TC, Patnaik A, Zarour H, Joshua AM, Gergich K, Elassaiss-Schaap J, Algazi A, Mateus C, Boasberg P, Tumeh PC, Chmielowski B, Ebbinghaus SW, Li XN, Kang SP, Ribas A (2013) Safety and tumor responses with lambrolizumab (antiPD-1) in melanoma. N Engl J Med 369:134-144
12. Robert C, Long GV, Brady B, Dutriaux C, Maio M, Mortier L, Hassel JC, Rutkowski P, McNeil C, Kalinka-Warzocha E, Savage KJ, Hernberg MM, Lebbe C, Charles J, Mihalcioiu C, Chiarion-Sileni V, Mauch C, Cognetti F, Arance A, Schmidt H, Schadendorf D, Gogas H, Lundgren-Eriksson L, Horak C, Sharkey B, Waxman IM, Atkinson V, Ascierto PA (2015) Nivolumab in previously untreated melanoma without BRAF mutation. N Engl J Med 372:320-330

13. Robert C, Schachter J, Long GV, Arance A, Grob JJ, Mortier L, Daud A, Carlino MS, McNeil C, Lotem M, Larkin J, Lorigan P, Neyns B, Blank CU, Hamid O, Mateus C, Shapira-Frommer R, Kosh M, Zhou H, Ibrahim N, Ebbinghaus S, Ribas A, KEYNOTE-006 investigators (2015) Pembrolizumab versus ipilimumab in advanced melanoma. N Engl J Med 372:2521-2532

14. Flaherty KT, Robert C, Hersey P, Nathan P, Garbe C, Milhem M, Demidov LV, Hassel JC, Rutkowski P, Mohr P, Dummer R, Trefzer U, Larkin JM, Utikal J, Dreno B, Nyakas M, Middleton MR, Becker JC, Casey M, Sherman LJ, Wu FS, Ouellet D, Martin AM, Patel K, Schadendorf D (2012) Improved survival with MEK inhibition in BRAF-mutated melanoma. N Engl J Med 367:107-114

15. Hauschild A, Grob JJ, Demidov LV, Jouary T, Gutzmer R, Millward M, Rutkowski P, Blank CU, Miller WH Jr, Kaempgen E, Martin-Algarra S, Karaszewska B, Mauch C, Chiarion-Sileni V, Martin AM, Swann S, Haney P, Mirakhur B, Guckert ME, Goodman V, Chapman PB (2012) Dabrafenib in BRAF-mutated metastatic melanoma: a multicentre, open-label, phase 3 randomised controlled trial. Lancet 380:358-365

16. McArthur GA, Chapman PB, Robert C, Larkin J, Haanen JB, Dummer R, Ribas A, Hogg D, Hamid O, Ascierto PA, Garbe C, Testori A, Maio M, Lorigan P, Lebbe C, Jouary T, Schadendorf D, O’Day SJ, Kirkwood JM, Eggermont AM, Dreno B, Sosman JA, Flaherty KT, Yin M, Caro I, Cheng S, Trunzer K, Hauschild A (2014) Safety and efficacy of vemurafenib in BRAF(V600E) and BRAF(V600K) mutation-positive melanoma (BRIM-3): extended follow-up of a phase 3, randomised, open-label study. Lancet Oncol 15:323-332

17. Robert C, Karaszewska B, Schachter J, Rutkowski P, Mackiewicz A, Stroiakovski D, Lichinitser M, Dummer R, Grange F, Mortier L, Chiarion-Sileni V, Drucis K, Krajsova I, Hauschild A, Lorigan P, Wolter P, Long GV, Flaherty K, Nathan P, Ribas A, Martin AM, Sun P, Crist W, Legos J, Rubin SD, Little SM, Schadendorf D (2015) Improved overall survival in melanoma with combined dabrafenib and trametinib. N Engl J Med 372:30-39

18. Escudier B, Eisen T, Stadler WM, Szczylik C, Oudard S, Staehler M, Negrier S, Chevreau C, Desai AA, Rolland F, Demkow T, Hutson TE, Gore M, Anderson S, Hofilena G, Shan M, Pena C, Lathia C, Bukowski RM (2009) Sorafenib for treatment of renal cell carcinoma: final efficacy and safety results of the phase III treatment approaches in renal cancer global evaluation trial. J Clin Oncol 27:3312-3318

19. Rini BI, Escudier B, Tomczak P, Kaprin A, Szczylik C, Hutson TE, Michaelson MD, Gorbunova VA, Gore ME, Rusakov IG, Negrier S, Ou YC, Castellano D, Lim HY, Uemura H, Tarazi J, Cella D, Chen C, Rosbrook B, Kim S, Motzer RJ (2011) Comparative effectiveness of axitinib versus sorafenib in advanced renal cell carcinoma (AXIS): a randomised phase 3 trial. Lancet 378:1931-1939

20. Motzer RJ, Hutson TE, Cella D, Reeves J, Hawkins R, Guo J, Nathan P, Staehler M, de Souza P, Merchan JR, Boleti E, Fife K, Jin J, Jones R, Uemura H, De Giorgi U, Harmenberg U, Wang J, Sternberg CN, Deen K, McCann L, Hackshaw MD, Crescenzo R, Pandite LN, Choueiri TK (2013) Pazopanib versus sunitinib in metastatic renal-cell carcinoma. N Engl J Med 369:722-731

21. Rini BI, Bellmunt J, Clancy J, Wang K, Niethammer AG, Hariharan S, Escudier B (2014) Randomized phase III trial of 
temsirolimus and bevacizumab versus interferon alfa and bevacizumab in metastatic renal cell carcinoma: INTORACT trial. J Clin Oncol 32:752-759

22. Postow MA, Chesney J, Pavlick AC, Robert C, Grossmann K, McDermott D, Linette GP, Meyer N, Giguere JK, Agarwala SS, Shaheen M, Ernstoff MS, Minor D, Salama AK, Taylor M, Ott PA, Rollin LM, Horak C, Gagnier P, Wolchok JD, Hodi FS (2015) Nivolumab and ipilimumab versus ipilimumab in untreated melanoma. N Engl J Med 372:2006-2017

23. Larkin J, Chiarion-Sileni V, Gonzalez R, Grob JJ, Cowey CL, Lao CD, Schadendorf D, Dummer R, Smylie M, Rutkowski P, Ferrucci PF, Hill A, Wagstaff J, Carlino MS, Haanen JB, Maio M, Marquez-Rodas I, McArthur GA, Ascierto PA, Long GV, Callahan MK, Postow MA, Grossmann K, Sznol M, Dreno B, Bastholt L, Yang A, Rollin LM, Horak C, Hodi FS, Wolchok JD (2015) Combined nivolumab and ipilimumab or monotherapy in untreated melanoma. N Engl J Med 373:23-34

24. Trunzer K, Pavlick AC, Schuchter L, Gonzalez R, McArthur GA, Hutson TE, Moschos SJ, Flaherty KT, Kim KB, Weber JS, Hersey P, Long GV, Lawrence D, Ott PA, Amaravadi RK, Lewis KD, Puzanov I, Lo RS, Koehler A, Kockx M, Spleiss O, Schell-Steven A, Gilbert HN, Cockey L, Bollag G, Lee RJ, Joe AK, Sosman JA, Ribas A (2013) Pharmacodynamic effects and mechanisms of resistance to vemurafenib in patients with metastatic melanoma. J Clin Oncol 31:1767-1774

25. Shi H, Hugo W, Kong X, Hong A, Koya RC, Moriceau G, Chodon T, Guo R, Johnson DB, Dahlman KB, Kelley MC, Kefford RF, Chmielowski B, Glaspy JA, Sosman JA, van Baren N, Long GV, Ribas A, Lo RS (2014) Acquired resistance and clonal evolution in melanoma during BRAF inhibitor therapy. Cancer Dis$\operatorname{cov} 4: 80-93$

26. Van Allen EM, Wagle N, Sucker A, Treacy DJ, Johannessen CM, Goetz EM, Place CS, Taylor-Weiner A, Whittaker S, Kryukov GV, Hodis E, Rosenberg M, McKenna A, Cibulskis K, Farlow D, Zimmer L, Hillen U, Gutzmer R, Goldinger SM, Ugurel S, Gogas HJ, Egberts F, Berking C, Trefzer U, Loquai C, Weide
B, Hassel JC, Gabriel SB, Carter SL, Getz G, Garraway LA, Schadendorf D (2014) The genetic landscape of clinical resistance to RAF inhibition in metastatic melanoma. Cancer Discov 4:94-109

27. Kaufman HL, Wong MK, Daniels GA, McDermott DF, Aung S, Lowder JN, Morse MA (2014) The use of registries to improve cancer treatment: a national database for patients treated with interleikin-2 (IL-2). J Pers Med 4:52-64

28. Heng DY, Xie W, Regan MM, Warren MA, Golshayan AR, Sahi C, Eigl BJ, Ruether JD, Cheng T, North S, Venner P, Knox JJ, Chi KN, Kollmannsberger C, McDermott DF, Oh WK, Atkins MB, Bukowski RM, Rini BI, Choueiri TK (2009) Prognostic factors for overall survival in patients with metastatic renal cell carcinoma treated with vascular endothelial growth factortargeted agents: results from a large, multicenter study. J Clin Oncol 27:5794-5799

29. Motzer RJ, Mazumdar M, Bacik J, Berg W, Amsterdam A, Ferrara J (1999) Survival and prognostic stratification of 670 patients with advanced renal cell carcinoma. J Clin Oncol $17: 2530-2540$

30. Birkhauser FD, Pantuck AJ, Rampersaud EN, Wang X, Kroeger N, Pouliot F, Zomorodian N, Riss J, Li G, Kabbinavar FF, Belldegrun AS (2013) Salvage-targeted kidney cancer therapy in patients progressing on high-dose interleukin-2 immunotherapy: the UCLA experience. Cancer J 19:189-196

31. Morse MA, McDermott DF, Daniels GA, Kaufman HL, Wong MKK, Aung S, Lowder JN (2014) High- dose (HD) IL-2 for metastatic renal cell carcinoma (mRCC) in the targeted therapy era: extension of OS benefits beyond complete response (CR) and partial response (PR). J Clin Oncol 32:5s (suppl; abstr 4523)

32. Daniels GA, Morse MA, Wong MKK, Kaufman HL, McDermott DM, Aung S, Lowder JN (2014) Improved median overall survival $(\mathrm{OS})$ in patients with metastatic melanoma $(\mathrm{mM})$ treated with high-dose (HD) IL-2: analysis of the PROCLAIM 20072012 national registry. J Clin Oncol 32:5s (suppl; abstr 9054) 